Ann. Biol. anim. Bioch. Biophys., 1979, 19 (6), 1837-1842.

\title{
Effects of diet and progesterone on the cellularity of parametrial adipose tissue in mice
}

\author{
par E. PALLIER *, Roberte AUBERT, D. LEMONNIER \\ Unité de Recherches sur la Nutrition ef l'Alimentation \\ $\mathrm{U}_{1}$ de I'INSERM, Hôpital Bichat, 170 Bd Ney 75018 Paris, France.
}

\begin{abstract}
Summary. 4-week old female mice received for 28 weeks a control or a high-fat diet, or one of these diets en riched with progesterone. The progesterone diets did not change food intake but reduced exploratory activity. Further, they increased the weight of two body fat depots ; in the parametrial fat pad, this augmentation was due to an increase in fat cell number. The effects of progesterone were the same in both the mice fed the control diet and in those rendered obese by the high-fat diet; the fat cells of the latter already showed hypertrophy and hyperplasia.
\end{abstract}

\section{Introduction.}

It is known that progesterone promotes the development of adipose mass (Hervey and Hervey, 1967). In experimental obesities in laboratory animals, increased adipose mass results from different modifications of adipose tissue cellularity. Indeed, the same obese animal may show an hypertrophy and/or an hyperplasia according to adipose localization. Female mice frequently show hyperplasia and hypertrophy of the fat cells of the parametrial adipose tissue, while the epididymal fat pad in the males rarely shows any signs of hyperplasia (Lemonnier, 1972 ; Lemonnier and Alexiu, 1973). The present experiment was conducted to determine how progesterone interferes with parametrial adipose tissue cellularity in both the control mice and in those rendered obese by a high-fat diet. We have tried to determine if the effects of progesterone upon adipose mass could be correlated with modification of food intake or spontaneous exploratory activity.

\section{Material and methods.}

Swiss female mice (Lessieux, Sèvres), born in the laboratory in litters of 7 to 11 pups and then raised in litters of 9 (Aubert et al., 1971), were weaned at 4 weeks. They were then divided into four groups and fed ad libitum either a control diet $\mathrm{T}$ with 9 p. 100 fat (in calorie) or a high-fat diet L (Lard) containing 72 p. 100 fat (in cal) (Lemonnier, 1972) or one of these two diets enriched with 0.5 p. 100 of progesterone (TP, LP) (progesterone, Merck). The mice were housed 5 to a polypropylene cage in

* Present address : Groupe de Recherches de Nutrition et Diététique, $U_{59}$ de I'INSERM, 40 rue Lionnois, 54000 Nancy, France. 
a room with an ambiant temperature of $22^{\circ} \mathrm{C} \pm 1$ and $12 \mathrm{hrs}$ of light. The diets were distributed every 2 days ; body weights were recorded weekly.

At 22 to 24 weeks, the mice were housed individually 15 days before the food intake was measured. The daily intakes were recorded over a 10-day period. At 24 to 27 weeks, spontaneous exploratory activity was measured in an « exploratory box $» 60 \mathrm{~cm} \times 60 \mathrm{~cm}$ square, having a clear plastic cover and a metallic screen floor divided into 30 equal squares by lines; the solid metal walls were $11.5 \mathrm{~cm}$ high. Metal barriers were arranged in the field to divide it into a series of alleys and " cul-desacs $»$. The investigator sat within view of the mouse and, over a 9-min period, recorded the number of squares the mouse entered, the number of times it reared on its hind legs, the time devoted to grooming and the number of fecal boli.

The animals were killed at 32 weeks, and the weight of the sartorius muscle, length of the femur and weight of the three fat pad depots (parametrial, perirenal and abdominal subcutaneous tissue) were recorded. Fat cell number and size were measured as previously described (Lemonnier, 1972) : the adipose cells on portions of histological sections were counted on slides, projected on the ground glass of a Projectina microscope at a magnification of $X 130$. The mean volume was calculated from their corrected area on the ground glass, and their number was estimated by the ratio of fat pad weight to mean adipose cell volume $\times 0.91$ ( 0.91 was the measured density of the pads).

\section{Results.}

Figure 1 shows the growth curves of the mice. When they were 32 weeks old, those fed the high-fat diet were 31 p. 100 heavier than the controls. Progesterone added to the diet increased body weight only in mice of the control group $(+12$ p. 100).

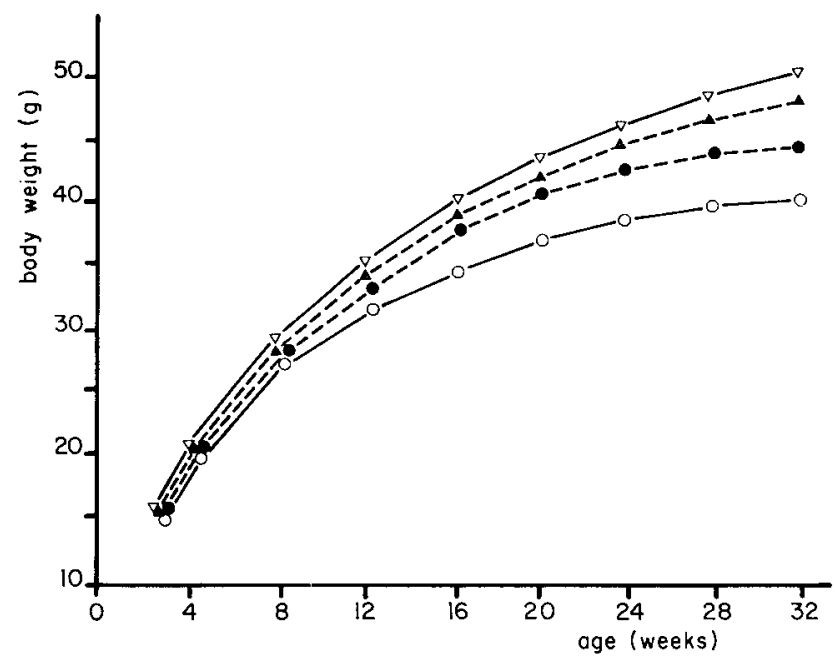

FIG. 1. - Growth curves of female mice fed ad libitum from weaning either a control diet $(T)$ or a high fat $\operatorname{diet}(\mathrm{L})$, or one of these two diets enriched with 0.5 P. 100 progesterone (TP, LP).

$\circ$ - Diet $T$

๑- - - Diet TP

$\nabla \longrightarrow$ Diet L

L- - - D Diet LP 
Whether expressed per animal or per unit of body weight, no significant difference in daily caloric intake was observed among the four groups (table 1).

TABLE 1

Food intake of female mice 22-24 weeks old fed ad libitum one of the 4 diets, $T, T P, L, L P$

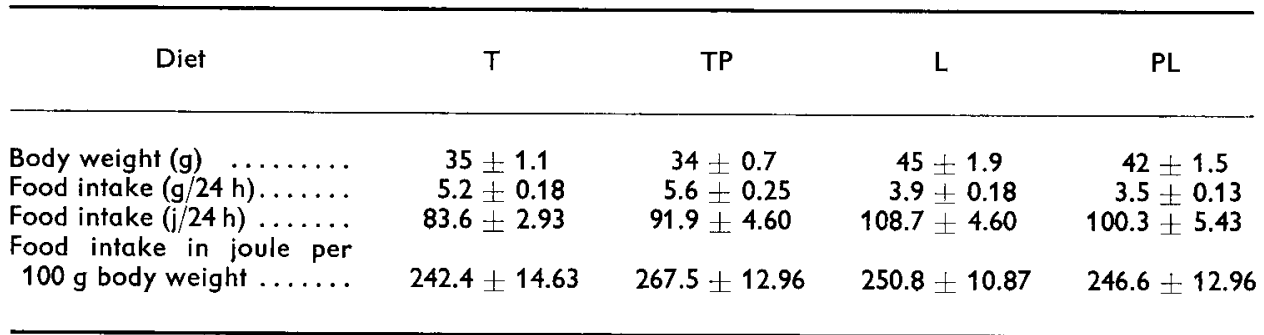

Number of animals per group : 10. $M \pm S E M$.

Spontaneous exploratory activity (measured by the number of squares the mouse entered over a 9-min period) (table 2 ) was significantly decreased $(P<0.05$ ) in mice fed the progesterone-enriched diet. However, the number of times the mice reared on their hind legs was the same in the control animals and in those fed the progesterone-enriched diets. The time devoted to grooming was significantly longer in both the groups fed a progesterone diet. No differences were found among any of the groups in regard to the number of defecations. Therefore, for none of the parameters measured could be noted any significant differences between mice fed the control diet and those fed the high-fat dief.

TABLE 2

Exploratory activity over 9 min in femole mice 24-27 weeks old fed ad libitum one of the 4 diets $T, T P, L, L P$

\begin{tabular}{lrrrrr}
\hline & T & TP & L & LP \\
\hline & & & & \\
\hline
\end{tabular}

Number of animals per group : $8 . M \pm S E M$.

* Significant difference $p<0.05$ between groups $T$ and TP, or L and LP.

Table 3 shows that the difference in body weight cannot be attributed to a difference in growth : the length of the femur and the weight of the sartorius muscle were similar in the four groups. In contrast, the high-fat diet increased the weight of the 
three fat pads from 67 to 116 p. 100 as compared to the control mice. Progesterone added to the dief increased significantly the weight of the perirenal adipose tissue in mice fed the control diet T (37 p. 100), but had no effect on mice fed the high-fat diet.

\section{TABLE 3}

Body weight and weight of different organs of female mice 33 weeks old fed ad libitum one of the 4 diets $T, T P, L, L P$

\begin{tabular}{|c|c|c|c|c|c|c|c|}
\hline Diet & & $T$ & & $T P$ & & L & LP \\
\hline $\begin{array}{l}\text { Number of animals } \ldots \ldots \ldots \\
\text { Body weight }(\mathrm{g}) \ldots \ldots \ldots \ldots \\
\text { Sartorius muscle weight }(\mathrm{mg}) \\
\text { Fenur length }(\mathrm{mm}) \ldots \ldots \ldots \\
\text { PAT weight }(\mathrm{g}) \ldots \ldots \ldots \ldots \\
\text { RAT weight }(\mathrm{mg}) \ldots \ldots \ldots \ldots \\
\text { SCAT weight }(\mathrm{mg}) \ldots \ldots \ldots\end{array}$ & $\begin{array}{c}39 \\
122 \\
16.6 \\
2.4 \\
354 \\
734\end{array}$ & $\begin{array}{l}15 \\
\pm \quad 0.9 \\
\pm \quad 3.5 \\
\pm 0.13 \\
\pm 0.22 \\
\pm 32 \\
\pm 69\end{array}$ & $\begin{array}{cc}* & 44 \\
& 127 \\
& 16.7 \\
* & 3.1 \\
* & 484 \\
& 925\end{array}$ & $\begin{array}{ll}12 & \\
\pm & 1.8 \\
\pm & 3.8 \\
\pm & 0.12 \\
\pm & 0.36 \\
\pm & 50 \\
\pm & 134\end{array}$ & $\begin{array}{c}52 \\
143 \\
16.9 \\
5.3 \\
648 \\
1230\end{array}$ & $\begin{array}{ll}12 & \\
\pm & 1.7 \\
\pm & 8.2 \\
\pm & 0.11 \\
\pm & 0.52 \\
\pm & 47 \\
\pm & 119\end{array}$ & $\begin{aligned} & 13 \\
& 49 \pm 1.0 \\
& 131 \pm 5.6 \\
& 16.8 \pm 0.20 \\
& 4.8 \pm 0.43 \\
& 634 \pm 50 \\
& 1190 \pm 90\end{aligned}$ \\
\hline
\end{tabular}
tissue.

PAT : Parametrial adipose tissue ; RAT : Perirenal adipose tissue ; SCAT : Subcutaneous adipose

* Significant difference $\mathrm{p}<0.05$ between groups $\mathrm{T}$ and TP. $\mathrm{M} \pm \mathrm{SEM}$.

Diet $L$ induced an increase of more than 50 p. 100 in the number and the size of parametrial adipose cells (table 4). The adjunction of progesterone to the diets had no effect upon fat cell size, but increased significantly $(P<0.01)$ fat cell number when groups TP and LP were respectively compared to groups $T$ and $L$.

TABLE 4

Parametrial adipose tissue cellularity of female mice 32 weeks old fed ad libitum one of the 4 diets $T, T P, L, L P$

\begin{tabular}{|c|c|c|c|c|}
\hline Diet & $\mathrm{T}$ & TP & $\mathrm{L}$ & LP \\
\hline $\begin{array}{l}\text { Number of animals............. } \\
\text { PAT weight }(\mathrm{g}) \ldots \ldots \ldots \ldots \ldots \\
\text { Adipose cell volume } 10^{3} \mu^{3} \ldots \ldots \\
\text { Total adipose cell number } 10^{6} \ldots \ldots\end{array}$ & $\begin{array}{c}7 \\
2.3 \pm 0.24 \\
317 \pm 36 \\
7.9 \pm 0.35\end{array}$ & $\begin{array}{c}11 \\
* \quad 3.1 \pm 0.31 \\
343 \pm 35 \\
9.4 \pm 0.82\end{array}$ & $\begin{array}{c}8 \\
5.1 \pm 0.22 \\
483 \pm 63 \\
12.2 \pm 0.96\end{array}$ & $\begin{array}{c}9 \\
5.3 \pm 0.40 \\
514 \pm 52 \\
14.2 \pm 1.24\end{array}$ \\
\hline
\end{tabular}

(*) Significant difference $P<0.05$ between groups $T$ and TP. $M \pm S E M$

\section{Discussion.}

Feeding an animal a high-fat diet ad libitum induced excessive increase in body weight as compared to the control mice fed a dief rich in carbohydrate. This overweight could be attributed to an increase in adipose mass as shown by the weight of the three fat pad depots. A marked sensitivity to high-fat diet has already been found 
in the parametrial adipose tissue of these mice : the fat cells of that fat pad showed hypertrophy and hyperplasia (Lemonnier, 1972). This type of obesity could not be related to hyperphagia : the food intake was reduced in weight, but expressed in terms of calories, it was slightly higher. Paradoxically, the spontaneous exploratory activity of these obese mice did not decrease; this is contrary to genetically obese mice (ob/ob) whose exploratory activity decreases (unpublished data).

Progesterone added to the diets only increased the body weight of the control mice. As in obesity induced by a high-fat diet, no overeating was observed, but excessive fat development could be related to a decrease of spontaneous activity. Progesterone promotes body weight gain (Bourdel and Jacquot, 1965) by increasing the adipose mass (Hervey and Hervey, 1967 ; Krotkiewski and Björntorp, 1976). The administration of progesterone seems to reproduce the physiological situation of pregnancy, weight gain being supplied by 30 to 40 p. 100 of fat (Hervey and Hervey, 1967). Birke and Archer (1975) and Guttman ef al. (1975) found variations in locomotor activity and behavioral response in an open field during the murine estrous cycle. The results presented here show that mice fed a diet rich in progesterone ambulated less and spent more time grooming in the exploratory box. The number of fecal boli were identical in both groups. As noted by Archer (1973), the question therefore is whether changes in ambulation and defecation are necessarily indicative of widespread changes in emotional responsiveness, or if, as suggested by Drewett (1973), this reflects feeding and activity changes. These results could be related to a decrease in spontaneous activity at the beginning of pregnancy (Slonaker, 1925) which has been correlated to a decrease in estrogen secretion (Yoshinaga ef al., 1969) and a high level of progesterone (Hashimoto et al., 1968). Somme of the progesterone effects can be attributed to the resulting hyperinsulinemia (Beck, 1969 ; Krotkiewski and Björntorp, 1976). According to the latter authors, progesterone in the female rat induces adipose cell hypertrophy in parametrial, perirenal and subcutaneous adipose localizations. This effect is more marked in the parametrial fat pad where the adipose cells are already larger, without any change in number. In contrast in our mice, progesterone increased cell number in genital adipose tissue without modifying cell size. Krotkiewski and Björntorp studied adult female rats, whereas our experiment used weaning mice. They also used medroxyprogesterone for shorter periods (4 and 10 weeks). The hypertrophic effect described by those authors may be correlated to the high level of insulin observed in the female rat treated with medroxyprogesterone. Plasma insulin was not measured in our mice, but hyperplasia could not be related to hyperinsulinemia. Repeated injections of insulin have no effect on adipose cell number, but do affect adipose cell size (Vost and Hollenberg, 1970 ; Salans ef al., 1972).

As in the control mice, fat cell size was unmodified in the mice rendered obese by a high-fat diet and given progesterone. These cells did not approach their maximal size (Lemonnier, 1972) ; only a slight increase in their number was observed. Progesterone therefore had the same effect on the cellularity of the control and the obese mice. The latter already presented hypertrophy and hyperplasia of perigenital adipose fat cells. 
Acknowledgments. - This work was supported by a grant from the INSERM (Contrat de Recherche libre no 75.4.024.7).

Résumé. Des souris femelles âgées de 4 semaines, reçoivent pendant 28 semaines soit un régime témoin ou un régime hyperlipidique, soit l'un de ces deux régimes enrichis en progestérone. L'administration de progestérone ne modifie pas les ingesta, mais l'activité exploratrice des souris est diminuée. Le poids de deux tissus adipeux est augmenté par l'ingestion de progestérone; dans le tissu adipeux paramétrial, cette augmentation de poids est due à une augmentation du nombre des adipocytes. L'effet de la progestérone est le même, que les souris reçoivent un régime témoin, ou qu'elles reçoivent un régime hyperlipidique, mais dans ce cas il y a hypertrophie et hyperplasie des cellules adipeuses.

\section{References}

ARCHER J., 1973. Tests for emotionality in rats and mice : A Review. Anim. Behav., 21, 205-235.

AUBERT R., SUQUET J. P., LEMONNIER, D., 1971. Effets à long terme de trois niveaux d'ingesta lactés sur les lipides corporels, la taille ef le nombre des cellules adipeuses de la souris. C. R. Acad. Sci., Paris, Sér. D., 273, 2636-2638.

BECK P., 1969. Progesterone enhancement of the plasma insulin response to glucose in rhesus monkeys. Diabetes, 18, 146-152.

BIRKE L., ARCHER J., 1975. Open-field behaviour of oestrus and dioestrus rats : evidence against an « emotionality » interpretation. Anim. Behav., 23, 509-512.

BOURDEL G., JACQUOT R., 1965. Progesterone et métabolisme azoté chez la rate adulte castrée. Arch. Sci. physiol., 19, 99-117.

DREWETT R. F., 1973. Oestrus and dioestrus components of the ovarian inhibition of hunger in the rat. Anim. Behov., 21, 772-780.

GUTTMAN R., LIEBLICH I., GROSS R., 1975. Behavioral correlates of estrous cycle stages in laboratory mice. Behav. Biol., 13, 127-132.

HASHIMOTO J. D., HENRICKS M., ANDERSON U., MELAMBY R. M., 1968. Progesterone and pregn-4-en 2 o $\alpha$-ol-3 one in ovarian venous blood during various reproductive states in the rat. Endocrinology, 82, 333-341.

HERVEY E., HERVEY G. R., 1967. The effects of progesterone on body weight and composition in the rat. J. Endocr., 37, 361-381.

KROTKIEWSKI M., BJÖRNTORP P., 1976. The effect of progesterone and of insulin administration on regional adipose tissue cellularity in the rat. Acta physiol. scand., 96, 122-127.

LEMONNIER D., 1972. Effect of age, sex, and site on the cellularity of the adipose tissue in mice and rats rendered obese by a high-fat diet. J. clin. Invest., 51, 2907-2915.

LEMONNIER D., ALEXIU A., 1973. Nutritional, genetic and hormonal aspects of adipose tissue cellularity. In VAGUE J., BOYER J. The regulation of the adipose tissue mass. Excerpta med., Intern. Congr., Ser., 315, 158-173.

SALANS L. B., ZARNOWSKI M. J., SEGAL R., 1972. Effect of insulin upon cellular character of rat adipose tissue. J. Lipid Res., 13, 616-623.

SLONAKER J. R., 1925. The effect of copulation, pregnancy, pseudopregnancy and lactation on the volontary activity and food consumption of the albino-rats. Amer. J. Physiol., 71, 362-394.

VOST A., HOLLENBERG C. H., 1970. Effects of diabetes and insulin on DNA synthesis in rat adipose tissue. Endocrinology, 87, 606-610.

YOSHINAGA K., HAWKINS R. A., STOCKER J. F., 1969. Estrogen secretion by the rat ovary in vivo during the estrous cycle and pregnancy. Endocrinology, 85, 103-112. 